\title{
Grey greening: quiet sustainability at auto salvage yards
}

PAVEL MAŠEK

Czech Academy of Sciences, Institute of Ethnology, Prague, Czechia; University of West Bohemia in Pilsen, Faculty of Philosophy and Arts, Department of Anthropology, Pilsen, Czechia; Max Planck Institute for Social Anthropology, Halle, Germany; e-mail: masek@eu.cas.cz

ABSTRACT Building upon my long-term ethnographic research at an auto salvage yard in Central Bohemia, I attempt to reveal through the lens of the 'quiet sustainability' concept that 'greening' can also be achieved quietly by the grey economy of breaking cars. The case of auto salvage yards shows that sustainability rises even through the yearning for profit. At auto salvage yards, economic meets eco-logic. Therefore, the unintentional sustainability reached by breakers opens space for debate on sustainability reached through the profit motive. While quiet practices leading towards sustainability might not lead to large-scale environmental or social changes, reaching sustainability through profitable practices seems to be a much more appealing way for many, with considerably larger pro-environmental consequences. Hence, these practices could provide inspiration for strategies towards a more sustainable society.

KEY WORDS auto salvage - breakers - car - profit - sustainability

MAŠEK, P. (2022): Grey greening: quiet sustainability at auto salvage yards. Geografie, 127, 1, 55-73. https://doi.org/10.37040/geografie2022127010055

Received October 2021, accepted January 2022.

CC Česká geografická společnost, z. s., 2022 


\section{Introduction}

It was a sunny but cold morning in November 2019, and all the car bodies in the yard were covered by lace blankets knitted out of frost. The naked, processed cars ready to be taken to a metal scrapyard looked like crafted goods from the display of a crystal glass shop in the tourist areas of Prague's Old Town, or like the excavated skeletons of future ancient beings. I was enjoying playing with my imagination while sipping coffee when Hynek's voice yanked me back: "Are you still sleeping or what? Come on, lend me a hand, will ya?" It was a day when we could no longer ignore the enormous pile of old, unsellable tires.

The auto salvage yard where I worked and conducted my research was divided into clear sectors; each of them had huge or small containers that functioned as intermediate stopovers for the trajectories of flowing waste. The order imposed on the yard fought against a persistent natural entropy. At some points entropy nevertheless dominated - since everything was always in the process of changing into something else (Ingold 2011, p. 3; Reno 2016, p. 9) - and one could see a slightly different world, such as the forgotten heavy metal beams absorbed by tree trunks and shrubs, or life emerging inside the metal skeletons of the oldest cars: nests of slow worms (slepýs) $)$, which are endangered and are thus a protected species in Czechia.

However, this was not the case with the tires. Hynek backed a pickup close to the heap, and we started to load it. Rubber tires are a liability for breakers; they have to pay a fee to get rid of them. Nevertheless, as in all similar situations, the fee is much less than the one an ordinary car user has to pay to discard her tires. Therefore, the apparent expenditure is an asset, in fact. It is usually a win-win situation because breakers can sell the used tires again or discard them for a laughably small fee.

"Why don't we just burn them?" I tried to induce a situation to find out more when we hit the road. "Are you fucking joking, mate?" laughed Hynek, and continued: "Like that cunt the other day. After I changed his tires, he refused to pay the fee for the old ones and wanted me to give them back to him. ${ }^{1}$ Just to save two fucking hundred (CZK), man. After a short hassle, I told him to fuck off with no need to pay anything. I'm sure the bloody wanker would have thrown the tires into the first ditch. We should care about nature, right?"

Hynek smiled. I mumbled my agreement and could sense that there was something more going on. It was not only the image of waste deliberately left in a ditch that troubled Hynek, but also the loss of potential money.

'Caring about nature,' expressed by Hynek, contrasted with the everyday practices on the ground. Everything that breakers found useless or valueless ended up inside the collection yard's containers or municipal solid waste bins; this was

1 Our salvage yard works as a service garage as well. 
mainly plastic components and window glass. Once a week, all the junk from the yard disappeared inside a bin lorry that later unloaded its squashed, anonymous contents into a nearby landfill or an incineration plant. On the other hand, everything valuable was safely stored in weatherproof warehouses.

One can find traces of the 'caring about nature' attitude at most auto salvage yards in Czechia. The range of this environmental awareness is relatively broad. First of all, when entering such places, one sees banners stating: 'ecological disposal (ekologická likvidace) of cars'. This clearly shows a strategy of adaptation to the gradual society-wide tendency to identify climate change culprits and the necessity to adjust to lawmakers' interventions. Nevertheless, on the other side of the scale in the everyday practices on the ground - we can find environmentally responsive behaviour that is not a result of any legislation, nor a deliberate outcome of any moral beliefs concerning the necessity of being environmentally friendly. It is a by-product of the yearning for profit - profit made from accidents (Martínez 2019 , p. 8). At the same time, it amounts to more than just policy and propaganda on the part of the auto salvage yard. While there is clearly an explicit goal to project the green image of auto salvage yards, recycling and reuse permeate the everyday activities of breakers without being the primary goal of these activities.

Therefore, at auto salvage yards, one can detect an environmentally responsive behaviour that we might call 'quiet sustainability' (Smith, Jehlička 2013). According to the authors of this concept, this kind of environmental responsibility exists and emerges in everyday practices rather than being generated by policies or PR campaigns. At the same time, practices of quiet sustainability are non-activist (Daněk, Jehlička 2021), nor are they a replacement or an alternative to the market economy, "or a response to its environmental or social failings, but rather a vivid demonstration that that is only part of life" (Smith, Jehlička 2013, p. 155). Practices of quiet sustainability can be considered a third way; that is, they are a way of reaching sustainability ${ }^{2}$ (as is desired in the context of current environmental events) without being framed by any legislation or constituting a bottom-up groundswell in the form of grassroots movements. Moreover, the environmentally friendly activities at auto salvage yards are often a result of informal practices, which I will discuss further below.

While one might perceive auto salvage yards as places that 'ecologically discard $^{3}$ unwanted and useless things (broken-down cars - in other words, waste),

2 When I talk about sustainability, I refer to the definition of what has been called sustainable development, that is, the ability to meet "the needs of the present without compromising the ability of future generations to meet their own needs" (World Commission on Environment and Development 1991).

3 Legislatively, the primary goal of auto salvage yards should be collecting hazardous waste end-of-life vehicles - and effectively recycling these vehicles. 
sustainability here does not pertain to the disposal of the cars, but rather to reusing spare parts and repairing seemingly totalled vehicles. As Martínez (2017) points out, waste is the opposite of sustainability, yet the brokenness or breakage of things that might become waste is never final; the practices of repair at auto salvage yards - which can be considered quietly sustainable practices - create new relationships and reconstitutions that do contribute to sustainability (Laviolette 2006). As Martínez puts it: “To repair is an act on the world: to engage in mending and fixing entails a relational world-building that materialises affective formations. It also settles endurance, material sensitivity and empathy, as well as more altruistic values oriented towards the sustainability of life" (Martínez 2019, p. 2).

Nevertheless, I do not consider breakers' practices to be borne out of the necessity of being environmentally responsive in the context of current events. Instead, I intend to point to the fact that widespread practices of quiet sustainability have been present in various human activities without needing any explicit law to motivate them, because these practices are not, in fact, consciously trying to achieve sustainability. Yet they are widely practised and do have positive environmental impacts (Smith, Kostelecký, Jehlička 2015, p. 224). The relative invisibility and marginalization of places like auto salvage yards and the practices happening there do not suggest that these positive impacts are somehow less significant and should be avoided or ignored. Quite to the contrary, these practices could provide inspiration for how to progress towards a more sustainable society (Reid, Sutton, Hunter 2010).

In this paper, I respond to the invitation to acknowledge "practices that are sustainable in outcome, but don't seek or claim to be" (Smith, Jehlička 2013, p. 155), and similarly to Sovová, Jehlička and Daněk (2021), I respond to Gibson-Graham's (2008) call to bring new worlds into being by making visible the range of existing diverse economies. Therefore, I attempt to move attention towards the widespread but not-much-recognized world of auto salvage yards - as part of the waste management world that prefers to be hidden (Sosna 2021) - to reveal that 'greening' can also be done quietly through the 'grey' economy of breaking cars. Inspired by the concept of quiet sustainability, I complement it with recent ideas on the practices of repair, maintenance, and care (Alexander 2012; Isenhour, Reno 2019; Martínez 2017; Martínez, Laviolette 2019).

This paper is based on the 22 months long ethnographic research I conducted from mid-2019 until mid-2021. I randomly chose an auto salvage yard in Central Bohemia, which later appeared to be the largest unofficial Hyundai and Kia salvage yard in Czechia. As a social anthropologist, I consider participant observation (Bernard 2006, pp. 342-386, DeWalt 2014, pp. 251-292, Spradley 1980) a key research method. Therefore, I worked as a breaker and participated in the everyday disassembly of cars during the research (I dismantled 64 cars during my fieldwork). Thus, I fulfilled the primary condition of participant observation - active 
and complete participation (Spradley 1980, pp. 60-62). Having in mind Virtová, Stöckelová and Krásná (2018) and their notion of ethical dilemmas of covert research, I did not want to practice anything like the undercover research. I introduced my research identity and explained my aims and intentions to all breakers in the yard. On and off, I would share and discuss partial research results and my thoughts with breakers during the whole research period. The data analysis builds on informal interviews, field jottings and field notes, which complemented the method of participant observation.

Relatively soon, I established a strong rapport with breakers at the yard. It allowed me to see breakers' quotidian informal practices. In the early stage of the research, I followed the advice of Ledeneva (2011, p. 729), who recommends using of so-called rear-mirror methodology - studying open secrets indirectly - while approaching sensitive matters of informality. Later, when my relationship with breakers reached a close friendship, I could extend the range of discussed topics. Both nicknames I use in this paper are emic expressions, and I explain their meaning further below.

The structure of the paper is as follows. I begin by showing some of the quotidian practices and situations taking place at an auto salvage yard, and then consider the informality in which the practices of breakers are framed. The last section focuses on the concept of quiet sustainability and its meaning for recent public and academic debates on environmentally responsive behaviour.

\section{Materialised potentials}

Breakers at auto salvage yards deal with the discards of other people. They are masters of seeing value and money where others see nothing more than unwanted rubbish. Auto salvage yards are places of secondary disposal ${ }^{4}$ and second chances (Soderman, Carter 2008). They are places that allow old cars to stay alive, despite the global political-economic system that is based on continuous production and money flow, forcing humans to waste things (Hawkins 2006, pp. 24-30). Auto salvage yards are second-hand marketplaces, sites of practical expertise and knowhow (Reno 2016, p. 125) and know-why. Some breakers do more than trade used auto parts and wrecked car components for use as a secondary source - mostly metal,

4 Cars within the yard have been disposed of by their previous owners - auto salvage yards are, in fact, locations of accumulated waste from past production. However, the breakers extract specific things that still hold some value for them (use-value and exchange-value). In this way, the salvage yard is a kind of waste sorting place. Individual usable parts are extracted for reuse - thus salvaged - and the unusable remainders, such as metal, e-waste, and plastic material, are sold and shipped away for recycling - at best. 
as its market is among the largest in the world's recycling economy (Alexander, Reno 2012; Minter 2013, p. 27, p. 31; Reno 2016, p. 121); they also repair totalled cars (totálky) and thereby rescue them from the waste regime (Gille 2007, pp. 34-35), returning them to the regime of consumer goods. In this way, breakers realise not only the potential of discarded cars but also the potential of their skills. Such activity might be perceived as both an environmentally responsive practice of breakers (vrakaři) and environmentally responsive consumption by their customers (zakoši). However, such behaviour is, in either case, motivated mainly (but not only) by calculative reasoning.

There is a plethora of auto salvage yards in Czechia. According to the Czech Environmental Inspectorate, about 600 auto salvage yards have been active in the past decade. ${ }^{5}$ Those are the legal ones. In practice, we can observe innumerable small operations that handle wrecked cars informally. One of the ways to hide the informal handling of wrecked cars - dismantling and storing them in places not intended for that purpose - is to run the business alongside a legal repair and service garage. These are places like the one where I conducted my fieldwork.

The treatment of wrecked cars ('end-of-life vehicles') is laid down by Directive 2000/53/EC of the European Parliament. ${ }^{6}$ According to this directive, the disposal of cars in Czechia must be done ecologically. As the number of formal auto salvage yards and places handling wrecked cars informally is comprehensive and based on intimate friendship and solidarity, obtaining formal documents confirming ecological disposal is easy to do, even for the informal places. However, it also creates a pledge between salvage yard operators. One day at the beginning of spring 2020, Pan Všemohoucí (Mr Almighty), ${ }^{7}$ the owner of our yard, went merrily to Teplice (North Bohemia) for a new Hyundai I40 that had been totalled. He planned to repair the car and sell it, as it was only a few months old. As I have mentioned, some breakers do not only break cars, but also repair them, often using parts of another car's body. They say that they 'glue' (lepí) such cars together.

After Pan Všemohoucí returned to the yard, he seemed to be somewhat disappointed. The car was not what he had expected: its top was damaged in a few spots, making it unmarketable as a whole. There was no way to fix its top; the car was good only for breaking up, which usually does not make sense when a breaker has purchased an expensive car. I asked Hynek why Pan Všemohoucí bought the car. Why did not he refuse the purchase when he had not even seen any pictures of

5 A database on totalled cars and auto salvage yards in Czechia is maintained on the website of the Ministry of the Environment, https://autovraky.mzp.cz/autovrak/ (accessed 20 January 2022).

6 A PDF of this directive is available at: https://eur-lex.europa.eu/legal-content/EN/TXT/PDF/? uri=CELEX:02000L0053-20130611\&qid=1405610569066\&from=EN (accessed 20 January 2022).

7 Pan Všemohoucí, literally 'Mr Almighty,' is how breakers underhandedly call the owner of the yard. 
the car beforehand? "He couldn't," answered Hynek, "a friend of his procured the purchase, and you can't just refuse, even if you don't like the fucking car at all." If he did refuse, Pan Všemohoucí would become untrustworthy and could possibly have difficulty staying within the profitable system of the wrecked car market.

Besides the disposal of cars and extracting their parts, some auto salvage yards both legal and informal ones - also obtain spare parts from elsewhere. One could find more than just car parts from totalled vehicles at the yard where I worked. Soon after entering the field, I noticed some brand-new parts that only had a coat of primer applied, such as car doors and other mostly metal parts, stored among used items in the warehouse. I asked Pan Všemohoucí about the origin of these parts. "From time to time, gypsies (cikáni) bring them. They say they sometimes find them somewhere near a scrap metal yard in Germany. It's bullshit, I know, but curiosity killed the cat (kdo se moc ptá, moc se dozví)".

Similarly, Pan Všemohoucí cooperated with a man who used to work as a manager for the Czech branch of Hyundai. Shortly after realising he was going to be fired, the manager secretly started to steal and hoard car parts that did not meet the quality requirements, hiding them in his office. These parts were rejected for use in new vehicles, and should have been ecologically discarded; yet they were still perfect enough to be informally sold to an auto salvage yard. The manager, who was convinced that moral law was on his side, made a deal with Pan Všemohoucí. As I learned later, the surreptitious sale of car parts like these by car manufacturer employees who have access to them is not unusual at all.

A common phenomenon is the cross-border import and export of cars both to and from Czechia in order to extract cheap spare parts from them; such vehicles are not transported as waste because they are sold with a foreign registration certificate. These cars are classified as commodities. While the transport of waste is tightly controlled, commodities can travel in a comparatively unobstructed manner. Wrecked cars cannot be classified as waste without being de-registered. At the same time, after their export, there is no requirement to confirm the proper ecological disposal of such vehicles unless they appear in the vehicle register. But they do not. This abundantly practised circumvention allows the ultimate recycling of motor vehicles without the necessity to confirm their official ecological disposal. Nevertheless, this informal dismantling and reusing of most of the car parts is not only economically profitable but also has a positive effect on the environment.

In this case, classification shifts serve as a vehicle of profit within the grey zone of the informal economy, but, at the same time, also support the re-use of car parts in the spirit of the officially promoted (green) circular economy. The classificatory game is not played only on the informal side of the field; Czech officials kick the ball around their half of the field, too. Transfers of vehicle ownership abroad are much cheaper than transfers made within the country. It might suggest a different approach towards the same thing: officials see a vehicle as a future 
problem - rubbish - that needs to be solved eventually. Breakers, contrariwise, see a vehicle as a resource, a chance to profit; thus, they play with classification and import a significant number of wrecked cars that never appear in statistics.

At first blush, it might sound like the level of environmental awareness among breakers is low. However, to be sure, breakers are aware of environmental problems and reflect upon them. Pan Vedouci (Mr Headman) ${ }^{8}$ would often complain about the 'consumption age' (doba spotrební), as he expressed it, which leads to the over-production of cars that become waste relatively quickly. In this sense, he saw the practice of leasing of cars, for example, as problematic. Leased cars are used for approximately three years of their life. As the cars are passed among several car users, they are often not cared for appropriately. There is no interest in further leasing the cars after three years or so, as their mileage is not attractive anymore, but their market price remains relatively high for being sold as used cars. The result is that these cars end up parked on huge private parking lots where they gradually lose their quality and value. "Cars are meant for driving, not for being parked for a more extended period somewhere. They become spoiled otherwise," Pan Vedoucí pointed out.

According to him, the production of cars intended for leasing causes a future environmental problem. It creates a situation where many products that once generated profit have no use anymore. Despite this, automotive producers keep producing more and more of these products, regardless of the associated environmental problems.

\section{Informally formal}

In the previous section, I provided a glimpse of some of the quotidian practices and situations taking place at the auto salvage yard. Although breakers might be seen as men $^{9}$ who ecologically discard the useless and unwanted, thus maintaining the social order (Douglas 2002) or servicing the boundary (Bauman 2004, p. 28), their own notion of their activity is far from this image. Ecological disposal of cars or preventing waste is not their goal. It is just a tool that enables them to make money. Breakers know that there are some rules they are obliged to follow, but they take them as a framework for meeting their own needs, that is, to profit through what seems to be junk. Since waste tends to be pushed to the margins of human perception, it often stimulates informal practices. Although the practices of breakers are framed by formal constraints, they are realised in an informal manner.

8 Pan Vedoucí, literally 'Mr Headman', is a pejorative nickname that the breakers use to refer to the yard owner's deputy behind his back.

9 I did not meet any female breaker during my research. 
Breaking a car at an informal place is a real 'shadow economy', if we follow economists' notion of informal economies, such as that of Schneider and Enste (2000, pp. 78-79), who define this economy as "unreported income ... hence all economic activities that would generally be taxable were they reported to the tax authorities". The economy at informal auto salvage yards is almost 100 per cent cash-in-hand economy. However, it is much more than this. We should certainly overcome economists' notion of informal economies, that is, "market-based production of goods and services, whether legal or illegal, that escapes detection by the tax authorities" (Smith 1994, p. 4), and consider informality as a regular part of everyday human life driven by not only calculative motivations - as a regular part of the formal. "Form' is an idea whose origin lies in the mind. Form is the rule, the invariant in the variable," writes Hart and continues: "The 'formal sector' is likewise an idea, a collection of people, things and activities that share an idea; but we should not mistake the idea for the reality that it partially identifies" (2006, p. 5). Therefore, we can observe the real world taking place in the informal. However, the informal is not random and independent of the form. Denying the informal would be to cling to a utopian ideal (Hart 2006, p. 6).

Economic anthropology - as a field that attempts to research and explain human economic practices in their widest scope - "is equated with cross-cultural philosophizing about human livelihoods in the broadest sense" (Hann 2018, p. 1708), which contrasts with the notion of modern economies associated with market commerce. Therefore, for the very purpose of opposing an economistic notion of economy, various different approaches have appeared, such as the concepts 'real economy' (Neiburg, Guyer 2019) and 'diverse economies' (Gibson-Graham 2006, Gibson-Graham 2008) that broaden the perspective on economy, or even call for people to take back the economy from governments and corporations (GibsonGraham, Cameron, Healy 2013).

Having these theoretical approaches in mind, I regard informality as being deeply woven into the fabric of society (Ledeneva, ed. 2018, p. VIII) and being present everywhere regardless of any particular politico-economic ideology, although in different forms and intensity. Informality is often associated with the periphery rather than the centre; nonetheless, in my view, it is its omnipresence that makes it central. Moreover, the case of auto salvage yards reveals that informality is central for their proper functioning: the entrepreneurial activity of breakers is rooted in and builds on informal practices.

Informality is not necessarily a transitory phenomenon, nor it is limited to places that have poor, socially unacceptable working conditions. Informal employment (Samers 2005), for example, does not necessarily provide a means of survival for the unemployed. It has been shown that informal practices exist among all segments of society (Makovicky, Henig 2017); it is a global phenomenon penetrating all aspects of public life (Polese et al. 2017, p. 3). Based on my fieldwork, I see 
informality as practices that take place on a daily basis as a part of the formal economy, which is similar to Millar's (2018, p. 130) observation about blurred categories of informal and formal vis-à-vis everyday practices on the ground. As Hart (2010, p. 151) puts it aptly, "[t] he formal/informal pair ... leaked into each other to the point of being often indistinguishable". One cannot have informal without formal and vice versa; "[ $t$ ] he formal and informal aspects of society were always linked" (Hart 2010, p. 143). They might seem to be opposites, but they are interconnected and interdependent. Hart (2010, p. 142) describes the formality of the formal as caused by the regularity of its order, a predictable rhythm. I believe the same applies to the informal. The world of informality can be rationalized the same way and made predictable just like the formal world. There are certainly some features informal economy shares with formal economy, such as unrestrained competition or even coercion, exploitation of employees, links with the formal state, or competition with the formal economy. All these features blur boundaries between formal and informal, and confirm their interconnection.

"Formal constraints limit but also enable informal ways of circumventing them", writes Ledeneva (2018, p. 5). The breakers' 'green', environmentally responsive behaviour, resulting from their informal 'grey' practices (as we could see in the previous section), has been made possible by circumventing the formal requirements of car disposal. Commonly, wrecked cars are supposed to be (ecologically) disposed of at auto salvage yards, and they are - or at least the official documents confirming the disposal state so. In fact, parts of the totalled vehicles return to the roadways by being 'glued' into another car. As I have already mentioned, the practice of repairing a vehicle using parts from another car's body is not unusual at all.

An event that happened during one beautiful Indian summer late afternoon in 2019 illustrates quite well the breakers' (informal) yearning for profit that results in environmentally responsive behaviour. Pan Všemohoucí arrived at the yard with a Kia Carens on a trailer. It was a totalled car, a valueless piece of scrap for an insurance company; but it represented the tremendous luck of a rare find for Pan Všemohoucí. The Kia was only four months old and, according to Pan Všemohoucí, also repairable. He was so excited that he brought ice cream for each of us along with the car.

We did not break it down as usual. Pan Všemohoucí decided to 'build' (postavit) that car again and return it to the roadways. We used parts of another car of the same brand and type that Pan Všemohoucí had bought only a couple of weeks before. Pan Všemohoucí asked me to 'peck' (vyzobat; dismantle) the older car's whole interior, thereby expressing confidence in me. During an ordinary pecking of a wrecked car, breakers destroy some parts of the car, such as cutting the wiring with an angle grinder (flexa) to save their time and effort; but the interior of the Kia needed to be dismantled carefully so that the parts could be re-used, including 
the wiring. The next day, after I finished pecking the interior, Pan Všemohoucí cut out - using a Sawzall (šukačka - literally meaning 'shagger') - parts of the older car's body that needed to be glued into the newer Kia.

Before the life of the Kia ended for its original owner, it was worth 590,000 CZK. Pan Všemohoucí bid on the car at an auction for 190,000 CZK, invested 100,000 CZK into the repair, and sold it for 400,000 CZK. No doubt he made a great deal, which resulted in 110,000 CZK profit. But profit was not the only reason why Pan Všemohoucí decided to purchase and repair the car. Salvaging value via repair, reuse, or recycling cannot be reduced to economic efficiency, because it is an inherent part of social relations and/or moral values (Alexander 2012; Alexander, Reno 2012; Isenhour, Reno 2019). All the breakers that I met during my fieldwork were obsessed with cars, and repairing totalled vehicles was explained as being a way to demonstrate their skills. Moreover, "it would be a waste not to buy such a nice car and put it together," said Pan Všemohoucí. Beyond this is the deep satisfaction and pure joy stemming from seeing a repaired vehicle that was previously labelled a total loss; this is similar to the scrap metal yard workers' satisfaction arising from work that is creative, skilled, and based on transformation (Sanchez 2020), or the enjoyment and pleasure involved in the second-hand practices described by Gregson and Crewe (2003), or the joy of unexpected finds among landfill workers observed by Reno (2016, pp. 98-135) or Sosna (2022, in press). The breakers' 'culture of repairing' (Smith, Jehlička 2013) characterises quiet sustainability, and as Martínez (2017, p. 349) puts it, "we can situate repair as part of the micro-powers, those that contribute to create transcendental narratives of reconstitution after wrongdoing or abandonment."

We might consider this particular example of breakers' quotidian practices resulting in environmentally responsive behaviour without the initial intention of being environmentally responsive to have a positive impact on the environment; yet it is often not labelled or valued as an example of sustainable development or sustainability. Similar to the case of food self-provisioning in the Central European area, breakers' activities "appear to be longstanding practices that the practitioners themselves, and the research and policy community, have not recognised or valorised in those terms" (Smith, Jehlička 2013, p. 149).

Concerning the event with the Kia mentioned above, another intriguing problem floated to the surface. I helped Pan Všemohoucí take the parts of the cars' bodies to a neighbouring village, where a tinsmith later 'glued' (soldered) them together. During the journey, Pan Všemohoucí started to talk about his conversation with the previous owner of the Kia. He suggested selling the car back to him after repairing it using parts of another car's body. The previous owner was speechless. Pan Všemohoucí did not mean to fool or defraud him by any means. Quite the reverse, he was fair and honest to him. However, the incompatible clash of two completely different perspectives took place here. 
The previous owner of the car was convinced that a glued car could not be safe. However, Pan Všemohoucí argued that gluing of cars used to be a common practice, and no one had found it weird. According to him, before Czechia became a member state of the European Union in May 2004, it was not easy to import a car from abroad. It was almost impossible to register such a car. One of the options to obtain a cheaper car was to buy a glued one. Upon entering the EU, legislation concerning the import of used cars changed and, therefore, registering these cars became much more manageable. Along with this change, the automotive industry started to blame imported used and glued cars for a higher number of traffic collisions. According to them, these cars were not safe at all. Opening the European used vehicles market meant lowering the automotive industry's profit, and their offensive move was a way to save their business. One can still find glued cars nowadays, but not to such an extent as two decades ago. When I asked Pan Všemohoucí about the safety of glued cars, he replied: "If you do it right, it's totally safe, but people usually don't think so, because they are being persuaded by someone who profits from a business with new cars." Pan Všemohoucí meant that a proper vehicle repair by using part of another cars body is another option, which does not have to be bad. In other words, practices of repairing totalled cars do not necessarily reduce the safety of these vehicles, and they do contribute to sustainability.

The argument mentioning car safety does not come out of the blue. Within the automotive industry, safety is one of the principal desirable features of cars; most car producers emphasize - along with comfort - the safety of their products. However, the constant improvement of car safety features, and the production and consumption of cars could be considered harmful to the environment. The pursuit of safety might lead car producers towards activities that can be understood as environmentally unfriendly.

The automotive industry is a key economic sector for many European states. Whenever this sector feels endangered, a culprit is found almost immediately. During the second half of 2020 , somewhere between the first and second wave of the COVID-19 pandemic in Czechia, something called 'pandemic motors' appeared in the EU and caused the ambitious aim of EU countries to cut carbon emissions produced by cars to hit a wall, which was partly welcomed with satisfaction by breakers at our yard. On the one hand, the number of discarded cars went down as the COVID-19 era shaped the lives of many humans, making their behaviour less predictable; feeling uncertainty about the future, people stopped trading in their old cars for new ones. On the other hand, breakers felt satisfaction because they 'hate' electric vehicles and favour diesel engines.

In short, pandemic motors describes a situation in which some Europeans, being afraid of using public transport, resorted to buying a car instead (EURACTIV.com 2020). However, they did not buy the green-dream-car of EU executives: the e-car. 
These days, cheaper used cars have been more in favour. Instead of expressing understanding, EU policy elites started to panic. They wanted to 'heal' the pandemic of 'ill' and dirty old cars to meet ethical consumerism obligations based exclusively on western models and ideas (Gregson et al. 2010; Smith, Kostelecký, Jehlička 2015 , p. 226) about environmentally-friendly vehicles. Therefore, the policy elites labelled old cars as agents of pollution and danger.

\section{Quiet sustainability monetised}

Although Smith and Jehlička (2013), the authors of the quiet sustainability concept, orient this concept around practices that do not relate, either directly or indirectly, to market transactions, everything else in the concept applies to auto salvage yards. Nonetheless, Jehlička explained to me that the connection to the market transaction is not a crucial condition for quiet sustainability. The informal practices of breakers represent an unforced form of sustainability - which the practitioners do not link directly to environmental or sustainability goals - that results in beneficial environmental outcomes. Although some breakers' practices at the yard can be considered environmentally unfriendly, the friendly ones prevail over them.

The case of auto salvage yards shows that sustainability can be reached even through the yearning for profit. I chose to regard the sustainability observed among breakers as quiet, because it is an unintentional by-product of practices having one main goal: profit. Recently, two new approaches towards sustainability have been trending. One of them advocates for abandoning the idea of sustainable development in favour of sustainable degrowth, which can be understood "as an equitable and democratic transition to a smaller economy with less production and consumption" (Martínez-Alier et al. 2010, p. 1741). Another one calls for complete nongrowth (Monsaingeon 2017, pp. 149-176). Yet, the sustainability reached by breakers, even though unintentionally, opens space for debate on sustainability reached through the profit motive. At auto salvage yards, the eco-nomic meets eco-logic. These two words - which form something of a Lévi-Straussian binary opposition these days - used to be conjoined twins: the Aristotelian idea of oikos a house occupied by a self-sufficient family - consisted of both the economic and ecologic part, and formed the essence of oikonomia (Hann, Hart 2011, pp. 18-20). It is a rather holistic perspective which, as I believe, is applicable in our times too.

According to Higgins (2015, pp. 1-11), who thinks within the context of oikonomia, the goal of sustainability has been to maintain balance among economy, environment, and society. In other words, sustainability is a matter of the interdependence of these three elements. Therefore, Higgins suggests approaching this complex issue as a system of the three elements that function together as a whole. If we look at sustainability as an integrated system, we can realise that it "adapts 
to its environment and behaves in ways determined by the interactions among its parts" (Higgins 2015, p. 9). The outputs of this integrated system come from how the system operates. While the ideas of sustainable degrowth and nongrowth build on slowing down and limiting the economic growth to preserve the environmental and social values, there might be another way to create balance among these three elements and reach sustainability, eventually - through the profit motive. The quiet practices leading towards sustainability might not lead to large-scale environmental or social changes, but they can serve as an example of reaching balance.

Yet, when we look at it from a broader perspective in terms of the policy community, practising totalled car repair and reusing car parts does not fit well the images and ideas about what modernity and sustainability could and should mean for societies. In other words, these practices are taking place at the 'wrong places' (Smith, Kostelecký, Jehlička 2015, p. 226) and in a 'wrong manner'. Paradoxically, the activities of breakers are based on capitalist logic - at least in terms of profit while at the same time, their 'culture of repairing' goes against it, ${ }^{10}$ as it goes against the constant production and consumption. Breakers gain profit, but their practices help keep things alive longer, thereby disrupting the profitability of market-based producers. In a time of overproduction, hyperconsumption, and acceleration (Crocker, Chiveralls, eds. 2018; Lipovetsky 2010; Vostal 2016), breakers' activities represent obstacles; they slow things down. Despite this, practices of repairing totalled vehicles and reusing their parts at auto salvage yards are often not considered to be contributions to sustainability by the general public. Nevertheless, the breakers' practices of repairing could provide inspiration for how to progress towards a more sustainable society through the yearning for profit - by finding the balance between economy, environment, and society.

The research of several scholars (Daněk, Jehlička 2021; Eriksen, Schober 2017; Millar 2012; Millar 2018; Reno 2009; Sosna 2016; Sovová, Veen 2020) has shown that places which are considered to be of a non-market character and/or dealing with discards, and therefore 'marginal', are often associated with activities that are usually perceived negatively and promoted as a coping strategy to provide poor individuals or families suffering from scarcity with an opportunity to enhance their livelihood or diet (in the case of food self-provisioning), or as an activist practice. Despite the creative (and sustainable) labour they engage in, people working at such places are often stigmatised rather than celebrated. The same scholars also demonstrate that all of this is too simplistic. The misunderstanding of

10 As one of the reviewers noted, breakers might not be able to do what they do without a constant influx of new broken cars, that is, without their production and consumption. Most likely, not to such an extent. However, auto salvage yards do not depend on the automotive industry entirely. The automotive industry is the crucial economic sector in Czechia. But even if there is something wrong with the automotive industry, breakers never lose; they can only gain. 
such places and the practices taking place there most likely stems from the current market-based politico-economic system's narrow idea of modernity, 'progress', or developed markets. We cannot explain either breakers' activities, or the behaviour of their customers, as coping strategies.

When I entered the field, I had somewhere in the back of my mind the general notion of mainstream society that auto salvage yards are places where the poorer segment of society would go shopping, as well as the notion that breakers only want to fool everyone. Both of these notions soon proved to be the result of prejudice. While all breakers I met were members of the middle-class and their work was not driven by the urge to fight scarcity, their customers represented all segments of society. Although the breakers' aim is to profit (which is more than compatible with the current global politico-economic system), their work is not driven purely by economic need. Neither are the people who shop at these secondhand marketplaces. During my fieldwork, in many cases, visiting an auto salvage yard appeared to be the only way to solve a problem with one's vehicle. Unlike mechanics (mechoši) in official service garages, breakers (who are mechanics themselves) offered solutions that could prolong the life of one's vehicle; this has a remarkably positive impact on the environment. Despite this, breakers or their customers are not activists fighting for a greener planet. Environmental reasons are not motivations for either of them, and they are not actively opposing growthdependent capitalist system. I am careful to not idealise the positive environmental impact of activities at auto salvage yards: yet we cannot avoid acknowledging the quiet 'green' behaviour that goes along with the practices of breakers.

\section{Conclusion}

In this paper, I aimed to reveal that there are practices and ways of reaching sustainability - through the profit motive - that are not recognised as such, and therefore, might be forgotten or ignored as marginal. To do so, I chose to frame these practices within the concept of quite sustainability which appeared to be of great help. I wanted to give a louder voice to breakers and their quiet practices with environmentally positive impacts, even if only for a moment, with the goal of stimulating discussion on this topic. If I stick to the game with colours that served as a quiet guide for this article, I argue that we can observe not only grey greening taking place at the end of the imaginary line ${ }^{11}$ stretching from production through consumption to disposal, but also greying of the proclaimed green

11 Disposal is not just the last act of a sequence that runs from production through consumption. The move of commodities is non-linear and unpredictable, as Gregson and Crewe (2003, p. 142) argue. 
happening at the beginning (or maybe the other end?) of the same line: the sphere of production Argenti and Knight (2015) assert that none of the green economy promises - to heal the wounds made by the predatory consumer economy while retaining the same patterns of production and consumption - passes through the sifter of neoliberal growth-logic unchanged. The case of pandemic motors shows this quite well. While sustaining top-down environmental awareness is limited by the market-based economy, societal and individual environmental concerns are part of diverse economies that work for societies and environments (GibsonGraham, Cameron, Healy 2013, pp. xiii-xxiii) in a much more 'natural' way. Market economy, in contrast to diverse economies, is not flexible, regardless of whether we call it 'green' or not. It is only a case of repainting steel-grey capitalism green (Howe, Boyer 2020). Human motivations are diverse, and therefore they cannot be seen only through the market-based economy perspective. If one acknowledges it, then one cannot be surprised that the expectations of lawmakers, whatever they are, are not always fulfilled.

\section{References}

ALEXANDER, C. (2012): Remont: work in progress. In: Alexander, C., Reno, J. (eds.): Economies of recycling: the global transformation of materials, values and social relations. Zed Books, London, New York, 255-275.

ALEXANDER, C., RENO, J. (2012): Introduction. In: Alexander, C., Reno, J. (eds.): Economies of recycling: the global transformation of materials, values and social relations. Zed Books, London, New York, 1-32.

ARGENTI, N., KNIGHT, D.M. (2015): Sun, wind, and the rebirth of extractive economies: renewable energy investment and metanarratives of crisis in Greece. Journal of the Royal Anthropological Institute, 21, 781-802.

BAUMAN, Z. (2004): Wasted lives: modernity and its outcasts. Polity Press, Cambridge.

BERNARD, H.R. (2006): Research Methods in Anthropology: Qualitative and Quantitative Approaches. Altamira Press, Walnut Creek.

CROCKER, R., CHIVERALLS, eds. (2018): Subverting consumerism: reuse in an accelerated world. Routledge, London.

DANĚK, P., JEHLIČKA, P. (2021): Quietly degrowing: Food self-provisioning in Central Europe. In: Nelson, A., Edwards, F. (eds.): Food for Degrowth. Routledge, London, New York, 33-44.

DEWALT, K.M. (2014): Participant Observation. In: Bernard, H.R., Gravlee, C.C. (eds.): Handbook of Methods in Cultural Anthropology. Rowman \& Littlefield, Lanham, 251-292.

DOUGLAS, M. (2002): Purity and danger: an analysis of concepts of pollution and taboo. Routledge, London, New York.

ERIKSEN, T.H., SCHOBER, E. (2017): Waste and the superfluous: an introduction. Social Anthropology/Anthropologie Sociale, 25, 3, 282-287.

EURACTIVE.com (2020): Pandemic Motors: Europeans snap up old cars to avoid public transport, https://www.euractiv.com/section/transport/news/pandemic-motors-europeanssnap-up-old-cars-to-avoid-public-transport/ (20.1.2022). 
GIBSON-GRAHAM, J.K. (2006): The end of capitalism (as we knew it): a feminist critique of political economy. University of Minnesota Press, Minneapolis, London.

GIBSON-GRAHAM, J.K. (2008): Diverse economies: performative practices for 'other worlds'. Progress in Human Geography, 32, 5, 613-632.

GIBSON-GRAHAM, J.K., CAMERON, J., HEALY, S. (2013): Take back the economy: an ethical guide for transforming our communities. University of Minnesota Press, Minneapolis, London.

GILLE, Z. (2007): From the cult of waste to the trash heap of history: the politics of waste in socialist and postsocialist Hungary. Indiana University Press, Bloomington, Indianapolis.

GREGSON, N. et al. (2010): Following Things of Rubbish Value: End-of-life Ships, 'Chock-chocky' Furniture and the Bangladeshi Middle Class Consumer. Geoforum, 41, 6, 846-854.

GREGSON, N., CREWE, L. (2003): Second-hand cultures. Berg, Oxford.

HANN, C. (2018): Economic anthropology. In: Callan, H. (ed.): The international encyclopedia of anthropology 4. Wiley Blackwell, Hoboken, Chichester, 1708-1723.

HANN, C., HART, K. (2011): Economic anthropology: history, ethnography, critique. Polity Press, Cambridge.

HART, K. (2006): Informality: problem or solution? World Bank PSD Forum 2006, Washington DC, $1-10$.

HART, K. (2010): Informal economy. In: Hart, K., Laville, J.-L., Cattani, A. D. (eds.): The human economy: a citizen's guide. Polity Press, Cambridge, 142-153.

HAWKINS, G. (2006): The ethics of waste: how we relate to rubbish. University of New South Wales, Sydney.

HIGGINS, K.L. (2015): Economic growth and sustainability: systems thinking for a complex world. Elsevier, San Diego, London, and Waltham.

HOWE, C., BOYER, D. (2020): Verdant optimism: on how capitalism will never save the world. Theorizing the Contemporary, Fieldsights, https://culanth.org/fieldsights/verdant-optimismon-how-capitalism-will-never-save-the-world (20.1.2022).

INGOLD, T. (2011): Introduction. In: Ingold, T. (ed.): Redrawing anthropology: materials, movements, lines. Ashgate, Farnham, 1-20.

ISENHOUR, C., RENO, J. (2019): On Materiality and Meaning: Ethnographic Engagements with Reuse, Repair \& Care. Worldwide Waste. Journal of Interdisciplinary Studies 2, 1, 1-8.

LAVIOLETTE, P. (2006): Ships of Relations: Navigating through Local Cornish Maritime Art. International Journal of Heritage Studies, 12, 69-92.

LEDENEVA, A. (2011): Open Secrets and Knowing Smiles. East European Politics and Societies, $25,4,720-736$.

LEDENEVA, A., ed. (2018): Global encyclopaedia of informality, Volume 1: understanding social and cultural complexity. UCL Press, London.

LIPOVETSKY, G. (2010): The hyperconsumption society. In: Ekström, K., Glans, K. (eds.): Beyond the consumption bubble. Routledge, New York, 25-36.

MAKOVICKY, N., HENIG, D. (2017): Introduction: re-imagining economies (after socialism): ethics, favours, and moral sentiments. In: Henig, D., Makovicky, N. (eds.): Economies of favour after socialism. Oxford University Press, Oxford, 1-20.

MARTÍNEZ, F. (2017): Waste is not the end. For an anthropology of care, maintenance and repair. Social Anthropology/Anthropologie Sociale, 25, 3, 346-350.

MARTÍNEZ, F. (2019): Insider's manual to breakdown. In: Martínez, F., Laviolette, P. (eds.): Repair, brokenness, breakthrough: ethnographic responses. Berghahn, New York, Oxford, $1-16$. 
MARTÍNEZ, F., LAVIOLETTE, P. (2019): Repair, brokenness, breakthrough: ethnographic responses. Berghahn, New York, Oxford.

MARTÍNEZ-ALIER, J. et al. (2010): Sustainable De-growth: Mapping the Context, Criticism and Future Prospects of an Emergent Paradigm. Ecological Economies, 69, 1741-1747.

MILLAR, K.M. (2012): Trash ties: urban politics, economic crisis and Rio de Janeiro's garbage dump. In: Alexnader, C. Reno, J. (eds): Economies of recycling: the global transformation of materials, values and social relations. Zed Books, London, New York, 164-184.

MILLAR, K.M. (2018): Reclaiming the discarded: life and labor on Rio's garbage dump. Duke University Press, Durham.

MINTER, A. (2013): Junkyard planet: travels in the billion-dollar trash trade. Bloomsbury, New York.

MONSAINGEON, B. (2017): Homo détritus: critique de la société du déchet. SEUIL, Paris.

NEIBURG, F., GUYER, J.I. (2019): The real in the real economy. In: Neiburg, F., Guyer, J.I. (eds.): The real economy: essays in ethnographic theory. Hau Books, Chicago, 1-25.

POLESE, A. et al. (2017): Introduction: informal economies as varieties of governance. In: Polese, A., Williams, C.C., Horodnic, I.A., Bejakovic, P. (eds.): The informal economy in global perspective: varieties of governance. Palgrave Macmillan, London, 1-14.

REID, L., SUTTON, P., HUNTER, C. (2010): Theorizing the Meso Level: The Household as a Crucible of Pro-environmental Behaviour. Progress in Human Geography, 34, 3, 309-327.

RENO, J. (2009): Your Trash Is Someone's Treasure: The Politics of Value at a Michigan Landfill. Journal of Material Culture, 14, 1, 29-46.

RENO, J. (2016): Waste away: working and living with a North American landfill. University of California Press, Berkeley.

SAMERS, M. (2005): The Myopia of "Diverse Economies", or a Critique of the "Informal Economy". Antipode, 37, 5, 875-886.

SANCHEZ, A. (2020): Transformation and the Satisfaction of Work. Social Analysis, 64, 3, 68-94.

SCHNEIDER, F., ENSTE, D.H. (2000): Shadow Economies: Size, Causes, and Consequences. Journal of Economic Literature, XXXVIII, 77-114.

SMITH, J., JEHLIČKA, P. (2013): Quiet Sustainability: Fertile Lessons from Europe's Productive Gardeners. Journal of Rural Studies, 32, 148-157.

SMITH, J., KOSTELECKÝ, T., JEHLIČKA, P. (2015): Quietly Does It: Questioning Assumptions about Class, Sustainability and Consumption. Geoforum, 67, 223-232.

SMITH, P. (1994): Assessing the Size of the Underground Economy: The Statistics Canada Perspective. Statistic Canada - Catalogue No. 13-604, 28, 1-25.

SODERMAN, B., CARTER, R. (2008): The Auto Salvage: A Space of Second Chances. Space and Culture, 11, 1, 20-38.

SOSNA, D. (2016): Heterotopias behind the fence: landfills as relational emplacements. In: Sosna, D., Brunclíková, L. (eds.): Archaeologies of waste: encounters with the unwanted. Oxbow Books, Oxford, 162-178.

SOSNA, D. (2021): Magnetism of Strangeness: Silenced Histories of Landscapes. History and Anthropology, 1-19.

SOSNA, D. (2022): Saving and wasting: the paradox of thrift in a Czech landfill. In: Alexander, C., Sosna, D. (eds.): Thrift and its paradoxes: from domestic to political economy. Berghahn, New York, 162-184.

SOVOVÁ, L., JEHLIČKA, P., DANĚK, P. (2021): Growing the Beautiful Anthropocene: Ethics of Care in East European Food Gardens. Sustainability, 13, 1-17. 
SOVOVÁ, L., VEEN, E.J. (2020): Neither Poor nor Cool: Practising Food Self-provisioning in Allotment Gardens in the Netherlands and Czechia. Sustainability, 12, 1-18.

SPRADLEY, J.P. (1980): Participant Observation. Holt, Rinehart and Winston, New York.

VIRTOVÁ, T., STÖCKELOVÁ, T., KRÁSNÁ, H. (2018): On the Track of C/overt Research:

Lessons from Taking Ethnographic Ethics to the Extreme. Qualitative Inquiry, 24, 7, 453-463.

VOSTAL, F. (2016): Accelerating academia: the changing structure of academic time. Palgrave Mills, Houndmills.

World Comission on Environment and Development (1991): Our Common Future. Oxford University Press, Oxford.

\section{ACKNOWLEDGMENTS}

The research on which this paper is based was funded by the Czech Science Foundation under grant GA20-06759S, and by the Max Planck Institute for Social Anthropology under V4Net doctoral scholarship.

I am grateful to Daniel Sosna, Barbora Stehlíková, and anonymous reviewers for their constructive criticism. I want to thank Petr Jehlička for his willingness to discuss the quiet sustainability concept, Patty A. Gray for the copyediting, and Chris Hann for his support. Special thanks go to Hynek, Jáchym, Prokop, Pan Vedoucí, and Pan Všemohoucí.

\section{ORCID}

PAVEL MAŠEK

https://orcid.org/0000-0001-9486-9775 